\title{
女性はコンクリート技術者として 生き抜けるか
}

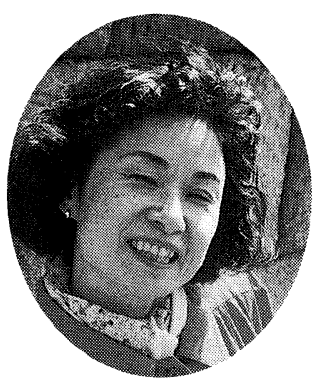

守明子*

約 20 年間，セメント系建築材料の製造と利用に関す る研究を, 女性であるが故の差別と嫌がらせを受けなが らも営々・肃々と続けてきた。常にセメントの臭いを嗅 ぎ，強いアルカリに皮膚を浸食されながらも，ここまで 仕事を続けてくることができたのは「業務の中断や挫折 は己自身のみならず現在差別され続けている狭くには職 場の同性を, 広くには多くの後輩の脚を引っ張ることに なる。それだけはしたくない。」という社会に対する強 い意識があったからである。さらにセメント・コンク リートの研究に女性が従事しているはずはないという社 会的思い込みは私自身の人生をより厳しくしてきた。

そのような時に, 差程身近に感じていなかったコンク リート工学編集委員会から執筆依頼をうけた。一瞬, 嬉 しかったのだが, 依頼先の一覧表から女性へのそれが僅 か一項目に限定されていて，こと技術に関するものは皆 無であることが判り, その嬉しさは瞬時にして霧散し怒 りと化した。本来，技術的な分野でも性的な分業はない はずである。この分野で活躍する女性技術者が少ないこ とは否めない事実ではあったとしても, 否, だからこ そ, 編集委員会にはたまさかではなく常にそのような女 性を発掘し社会を啓蒙していくという前向きの姿勢を是 非もって欲しい。せっかくの機会なので, 日ごろ, 憤㣴 やるかたなく思っていることのほんの一端を, 後輩のた めのみならず日本コンクリート工学協会のためにも述べ させて頂きたい。

今年の就職活動も女子学生にとっては悲劇的であった (ある)。男女雇用機会均等法ができてかなりの時間が 経つのに相変わらずである。何故だろうか。それはこの 法律には, 法の精神の浸透のために最も強力な武器とな る罰則規定がないからである。多くの女性はこれを恨 み, 今でも身をすり減らしながら生きている。当初盛り 込まれていた罰則規定は, 当時の担当省庁の責任者が己 の次の職のために妥協した結果亡, 当時, 報道されてい た。しかもそれは女性であると聞く。女性は筋を通し， 社会正義を貫くと，一般には言われている。しかし，権

* もり・あきこ／通商産業省 工業技術院 九州工業技術研究所 ファイン素材部 環境材料研究室
力の近くに位置する女性も増えてくると，片方の性に生 まれてきたが故に大きな不利益を被らざるを得ない人々 を生産する側に立つ人もでてくる。真にゆゆしきことで ある。

一方，企業における女性技術者の定着率は残念ながら 低いようである。それは本人の意思では如何ともしがた い最も遅れた日本独自の社会的状況のためでもある。そ のひとつは家庭内における差別である。結婚すると，ま ずは家事を，そして子の誕生に伴う育児の負担を避けん がために，さらには男の甲斐性としての面子のために妻 が社会で働くのを辞めさせようという非近代的な男性が 日本ではいまだに主流派から転落していない。次に税制 における差別である。現在の税制では配偶者に対する扶 養控除が他のそれと比較すると格段に大きく，また配偶 者というだけで健康保険の掛け金は払わずしてその恩恵 には浴することができる。何故にこのような税制が敷か れているのか, 意図するところを真剣に考えて欲しい。 一見, 配偶者 (ほとんどが女性) を優遇しているように 思えるのだが, 実際には多くの女性が社会で働きたいと 考えても㗢くことができなくなるという状況を作り出 し，結果として女性の低賃金状態を固定的なものとして いる。職場の上司は若い女性技術者を甘やかす必要は全 くない。しっかりと育てて欲しい。そして, 女性技術者 には社会の一員として生きていくという気概をもって事 に当たり，尻切れ蜻蛉などということのないようにと望 みたい。尻切れ蜻蛉では後に続く同性に負の債務を負わ せることをぜひとも認識して頂きたい。様々な困難が あっても, 若いあなた自身があなたらしく生きようとす ればするほど, 精神的のみならず経済的な自立は不可欠 なもの。若いあなたが転ぶと, あとはドミノ。甘えるこ となく人生を切り拓くほどの意欲をもって，しなやかに 且つしたたかに社会の中で生きて欲しい。さらには然る べきポストに就いて欲しい。女性のポスト就任者が増え ることは男性にとってむしろ歓迎すべきこと。女性が生 きやすい社会, それは男性にとっても生きやすいもので ある。

さて, 私自身, これまでの研究者生活を振り返ると, 
幼子達を抱え一人悪戦苦闘を演じざるを得なかった。夜 遅くまで実験と論文作成に明け暮れる男性研究者を常に 羡ましいと思ったものである。時として子供が足手まと いと感じられたのも正直なところである。しかし, 今, 周囲の彼らを観察するに，女性は現在の社会的な閉鎖性 から「鬼」にはなかなかなり難いとしても，「龟」には 充分なり得る，と思う。そこのところを拙文を読まれる 企業には是非打考頂きたい。そして，いわゆる仕事の できる彼らには生活の達人が多いことに気づく。今の社 会では, まだまだ家事・育児という日常業務は女性に重 くのしかかっており，しかも365 日休睱なしでは時とし て放り出したくもなる。しかし, 気紛れは許されない。 片や研究には常に工夫とたゆま好力が要求されるが, このような側面は広く一般に技術者として仕事そのもの を継続していくことにも繫がると考えられる。ひょっと すると, 3 Kの象徵のように言われているが故に女性か ら敬遠されがちなセメント・コンクリートに関する仕事 は, 紙の上の答えを出すことのみに汲汲として人間本来 の精神的成長を阻害する教育システムに乗せられた社会 を知らない男性よりも, 押し潰されそうになりながらも ふんばる女性にぴったりなのかもしれない。しかし，そ れには社会の偏見と仕組みとを変えて行かねばならな い。

翻ってコンクリート技術を眺めるに，セメント・コン クリートは都市を形成する重要な基幹的材料であるにも 拘わらず，「コンクリートジャングル」「重厚長大すなわ ち $3 \mathrm{~K}$ で時代幄れ」などの言葉に象徴されるように, その社会的評価は決して高くはない。これは日本コンク リート工学協会そのものの評価とも蒀がっているように 私には思える。そして, このような業界・学会の置かれ ている状況は, 今の女性技術者が置かれている状況亡極 めて類似している。そこで, 日本コンクリート工学協会 が女性技術者の就職運動に学会活動の一環として取り組 むことをここで提案したい。政治の社会では閣僚ポスト に関してクォーター制が論じられるが, 女性技術者が活 躍する場のとりかかりとしてコンクリート分野において もこの制度が論じられても良い時期にきていると思う。
人類の半数を占める女性の能力を生かさないのは，大き な社会的損失でもある。

ところで, 遥か昔のことになってしまったが, 学位取 得のころを想い出す。こつこつと実験を重㸚学位論文と してまとめ提出した。ところが, 内容的には問題なしと しながらも手続き書類の年号表示が元号になっていない という理由で，こともあろうに主査となる教授から門前 払いを喰らった。元号の持つ意味ならびにその社会的役 割について日ごろから思いを巡らし, 性差別の原点と考 え，その表示に嫌悪感さえ抱いていた者にとっては，日 本国憲法に保証された思想信条の自由をも侵すものであ り, 基本的な人権が蹂䠰される耐え難いものであった。 江戸時代の踏み絵である。このような時代錯誤的なこと が学問の府において, 堂々とまかり通っていることには 驚いたが，よくよく考えてみると，これも提出者が女性 であるが故の差別であることに気づき, 怒りは個人的な レベルを越え，一般女性に対する挑戦・攻撃であるとい う認識に変わっていった。

さてさて，話しが飛んでしまったが，この不景気の世 の中で仕事にあぶれた人は増加の一途を辿っている。こ のような時にこそ良い人材を集め足腰を強化したいとは 企業の誰しもが考えることである。しかし，仕事がない ことには採用もままならない。したがって，コンクリー 卜関連企業の社会的意義は「いかにして仕事を作るか」 これに限ると思われる。また, コンクリート業界の発展 の鍵は，これまでの「どのようなコンクリートを製造す るか」ではなく, むしろ「どのような建築物を生産して いくか」に視点を移して行くことではないかと。そし て, いかに多くの優秀な女性コンクリート技術者を採用 するかに脚かっているように思う。前向きの姿勢をもつ 女性コンクリート技術者の採用拡大，働くことができる にも拘わらず働こうとしない男性の淘汰が，この先，企 業として確実に生き残れるためのキーポイントなのかも しれない。そうすれば，コンクリート業界の社会的評価 も高まり, 世のコンクリート研究者も発奮して, それが 日本コンクリート工学協会の発展にも䌘がるのであろ う。

\title{
《図書 案 内》
}

\section{コンクリートの製造システム研究委員会報告書}

\author{
A 4 判・ 60 ページ／定価 3200 円 (税这), 会員特価 2800 円 (税这) /送料 360 円
}

・申込先：(社) 日本コンクリート工学協会・管理課「書籍販売係」

于102 千代田区麦町 5-7 TBR 708 号 /電話 (03) 3263-1571 (担当 : 宇野)

〈申込方法〉 書籍名・送付先を明記のうえ，前金（現金書留）にてお申込み下さい。 